\title{
1. Territoriality and the European infrastructure system
}

\section{INTRODUCTION}

The territorial state is at the core of the international system, with each state seeking to assert its territoriality (through a set of enabling strategies) over the portion of the earth's surface that is recognised by all other states as being under its jurisdiction (Taylor 1994, 1995). Central to these territorial strategies is the provision of territorially extensive economic infrastructures (see below for formal definition) with sufficient capacity and development to enable the intense and prompt flow of both state and non-state tangible and non-tangible resources to enable the state to control, integrate, secure and develop that territory under its jurisdiction (Turner 2018, 2020). This underlines that the state needs to offer universal access to the infrastructure system as a means of enabling its territoriality. These territorial strategies have been subject to the adaptive tensions formed by economic, social and technological change. One such adaptive tension was and is the trend towards regionalism within the international system, where regionalism is defined as the formal and informal processes of economic, social and political interaction, interdependence and even integration across and between contiguous and semi-contiguous territorial states (Dehousse et al. 1990, Söderbaum 2012). ${ }^{1}$

This chapter explores the form and nature of the adaptive tension of regionalism on the territorial state largely within the context of the pressures this places on national infrastructure systems (NIS). In particular, the chapter will focus on the exemplar of this trend provided by the ongoing processes of European integration and how this is creating adaptive tensions promoting the re-infrastructuring of NIS as a response to these forces of change. In so doing, the focus is upon contemporary events and processes, not upon the history of regionalism and regional infrastructuring across Europe. ${ }^{2}$ Initially the chapter explores the form 
and nature of regionalism within the context of state strategy, arguing that it represents a strategy of co-operative territoriality between states. Building on this conceptual development, the chapter moves on to examine the interface between territoriality and regionalism in NIS across Europe. In so doing, the notional adaptive tensions upon NIS created by the process of regionalism through both formal and informal processes of economic integration will be examined.

\section{THE NATURE OF STATE STRATEGY}

The state here is defined as a territorially bounded entity that seeks to secure and preserve its territoriality through a series of mutually supporting policy actions formed exclusively and implemented by a centralised institutional system across a demarcated and (normally) contiguous space (Krasner 1978, Auster and Silver 1979, Skocpol and Theda 1979, Nordlinger et al. 1988, Kofman 2007). These sets of actions to establish, preserve and enhance state territoriality lie at the core of state strategy. State strategy is treated as the exclusive area of the state, reflecting notions of sovereignty where such a strategy is formed and undertaken in a discretionary manner autonomous of socio-economic pressures (Skocpol 1985, Mitchell 1991, Jackson and James, 1993). Expressed in functional terms, state strategy can be synthesised into two overlapping elements (see for example Cerny 2010). The first are those actions by the state that have the demarcated territory over which the state exercises sovereignty as their objective: so-called 'territorial strategy'. The second aspect of state strategy is how the state (given emergent inter-state interdependencies) seeks to position itself in an international system of states to secure its core territorial and extra-territorial objectives: defined here as 'geostrategy'.

In terms of territorial strategy (see Sack 1983, 1986), the objective of the state is to assert legitimate control across a territory. This rests upon the notion that not only does the state have the legitimate right - by both the population of a territory and other states (Taylor 1995) - to assert control over the territory, but also that it has the capability to undertake the measures to assert its territoriality (Vollaard 2009). This reflects that state strategy does not solely depend upon the state possessing the monopoly of physical violence to enable its rule-making authority (Weber 1968); it also depends upon the ability of the state to provide the public goods that legitimise its right to assert its territoriality within the demarcated space (Holsti 1996, Fukayama 2004, Lemay-Hébert 2009). 
As such, the core objective to such strategy is to ensure that the state meets its own and its population's desire for internal order, external security, socio-economic cohesion and the promotion of economic growth (see for example Painter and Jeffrey 2009). Conventionally, this treats the state as a 'bordered power container' (Giddens 1985) with limited or no overlap between respective state territorial jurisdictions (Scholte 2005).

The second dimension of state strategy is geostrategy, which reflects the need for states to position themselves to support their territorial objectives within the system of states (Skocpol 1985, Moisio 2019). Geostrategy - as defined here - concerns those actions (both formal and informal) by the state that seek to manage the evolution and consequences of extra-territorial events and processes that impact the capability of the state to meets its territorial objectives (Walters 2004, Browning and Joenniemi 2008). These formal geostrategic actions involve a mix or sole use of geopolitical and geo-economic techniques to influence the behaviour of other states (as well as non-state agents) so that they work for (or at the very least not against) the interests of the state and its territorial objectives (see for example Katzenstein 1978, Taylor 1994, Cerny 1995, Keohane 2002). Alongside these methods are those actions to manage the everyday interactions between states across contiguous and semi-contiguous space where there is evident spillover/territorial overlap between states. These result in the actions of a state in one territory impacting on another. These actions are often unintentional but reflect longstanding socio-economic and political links (Arrighi 1994).

The interface between territorial and geo-strategies underlines that there is no neat divide between domestic and international systems (Agnew 1994), and that not all events that happen in a national territory are national events (Brenner 1999, Sassen 2013). Thus, according to Agnew (2005), the state and territory are no longer synonymous as territoriality can impact on and be impacted by political and socio-economic processes beyond the borders of the state. This stresses that strategy is no longer focused purely on activity within defined borders (see also Painter 2010, Carpenter 2019). Furthermore this process underscores that the conventional notion that discretionary territorial strategy is curtailed by globalisation is too simple a perspective (see for example Weiss 2005). The tensions acting upon discretionary state strategy are formed by a mix of contemporary issues (such as the trend towards globalism) and longstanding factors by territorially overlapping social, political and economic processes (see for example Taylor 1994, Sassen 2013). 
Such complexity reflects that territoriality is not simply the outcome of a single state's actions but of an assortment of behaviours by a range of actors. Furthermore some components of territorial strategy are not strictly national as they operate in a larger operational space that can involve the debordering of activities beyond established state boundaries. Thus the conventional territorial function of sovereignty can also be configured within imperial (where one state asserts and contests rights over others), integrationist (pooling of sovereignty) and globalist (networks that are defined by geography) configurations (Carpenter 2019). Nonetheless given this context, the state will develop strategies to reflect its own interests and to also manage the needs of its territory even if it cannot directly control all the forces acting upon it (Harvey 2010). The legacy of these processes is that the public good elements of the state in terms of security, control, cohesion and growth are to some extent externally influenced (Agnew 2000). In some cases, states may be proactive in this adaption through - for example - applying the logic of the competition state where the state seeks to increase both the permeability of borders and penetration of territory by international forces as a partial enabler of territorial strategy (Cerny 1995, Weiss 2005). The efficacy of state strategy to adapt in a discretionary manner to these tensions will reflect the relative power of the state. The larger regional and even global hegemonic states have more capability to shape the system to their advantage than smaller or less economically powerful states. This renders smaller states into a position of vulnerability (Katzenstein 2003). This can - amongst states - stimulate the development of alternative less independent/more interdependent state strategy as a means of securing their territorial objectives (Palan et al. 2001). It is within such contexts that a clear strategic rationale for regionalism can emerge (see below).

\section{REGIONALISM AS CO-OPERATIVE TERRITORIALITY}

The commonality underpinning the rationalisation of regionalism as state strategy rests upon the extent to which the flows between two or more territorial states and the mutual penetration of space that results create common territorial problems (Hass 1958, Keohane 2002, Gritsch 2005). ${ }^{3}$ These can emerge through common security issues, cross-border cohesion, the mutual desire for growth and competitiveness, the push for sustainable economic systems and the desire to sustain territorial control in the face of more open territorial systems. These common interests 
form the foundation for inter-state co-operation/co-ordination to solve these common problems for mutual benefit. Such commonality is formed against a context where freer mobility, the erosion of flow filtering and discrimination between the states works for mutual advantage. This is based upon the existence of mutual confidence by each state that another's actions do not compromise any other state's territoriality. Thus, regionalism results from the actions of self-interested rational states in a global system of states that seek to preserve their own (aligned) interests (most notably their survival) through collective action. Such strategies limit state discretion through the pooling of specific activities where this is a more effective means of attaining territorial objectives through co-operation and co-ordination (Axline 1994, Payne and Gamble 1996, Rosamond 2000, Schimmelfennig 2010, Börzel 2016). This process is underpinned and legitimised by the notion that these states leak power across each other's borders. Consequently inter-state co-operation seeks to ensure that such processes are managed so as to mutually support each other's territoriality (Jackson and James 1993, Taylor 1994, Mann 1997). Indeed Vaubel and Willett (1991) argue that states have an incentive to engage in regionalism where cross-border externalities result in the under-production of public goods, where international co-operation occurs in the production of public goods and where non-co-operative behaviour produces sub-optimal outcomes (Axelrod 1984). The efficacy of regional processes to support state territoriality relies upon trust and commitment between partners to ensure the mutual legitimacy of flows. Such legitimacy is based on a commonality of risk and the alignment of the objectives of co-operating states.

Despite this trend toward regionalism, there is little evidence of any sense of an independent supranational strategy being developed in any regional grouping either at the territorial or the geo-strategic level (Vollaard 2009). For most regional groupings, bar the EU (see below), there are limited erosions of internal borders, and no real intention for the group to develop any real common geostrategic positions beyond trade. Consequently - in most regional agreements - territorial and geo-strategy remain the sole preserve of the state. Wissel (2014) argues that regional bodies, even where they are most developed (such as in the case of the EU), lack infrastructural power with there being no direct link to civil society, with regionalism being an elite-driven process devoid of popular consensus. Thus regionalism does not erode the salience of the state in its territory or its position as a building block of the global system. Regionalism does though create an adaptive tension upon 
states to which they need to respond (Brenner 1999). As suggested, any adaptations occur without fundamentally altering the nature of the territorial state as the challenges of regionalism are often at the periphery of the main objectives of territoriality (Mann 1984, Hurrell 1995, Weiss 1998). Regionalism does not tend to penetrate deep into the state's socio-economic and political structures, with co-operation being limited in scope and impact upon a state's territorial functions (see for example the work of O'Tuathail et al. 1998, Weiss 2005).

This strategic adaption to the tension created by regionalism results in strategies that can best be characterised as co-operative territoriality. This is a discretionary strategy followed by states to adapt to tensions created by the rising complexity, intensity, extensity and velocity of cross-border flows and their legacy for state territoriality. Co-operative territoriality represents a strategy of proactive engagement between states to enhance the efficacy of their own strategies, often (though not always) via co-ordinating supranational/international structures (Held et al. 2000). The strategy is based on the notion of inter-governmental co-ordination as advanced by Hettne and Söderbaum (1998). This stresses strategies of co-operative action by states for mutual benefit based on rising interconnections between economies with minimal loss of sovereignty (Cini 2010). This process can reflect a mutualisation of risks (both internal and external to the states) where state territory is penetrated by both formal and informal interactions that can be both legitimate and illegitimate (see below). As such, territoriality cannot neatly be delimited by borders (see for example Agnew 1994). Thus, as Brenner (1999) stresses, co-operative territoriality as a strategy is rationalised through the recognition that the state is not a self-enclosed block of space but forms strategy on the recognition that it operates on a series of overlapping domains. This does not change the territory of the state, but it does require a re-scaling so as to enable it to create and manage socio-economic political relations that impact upon its territoriality.

Conceptualising regionalism as co-operative territoriality embeds the analysis in this research within intergovernmental approaches to the study of regional integration, with the process ultimately shaped by domestic political economy (Moravcsik 1993, Cini 2003, 2010). This eschews any sense that any pooling of sovereignty generates an embedded dynamic process of ever closer integration (Keohane and Nye 1975, Rosamond 2000). ${ }^{4}$ These approaches reflect realist methodologies to the study of the subject matter, where the territorial state seeks only compromises (based on inter-state bargaining) regarding its sovereignty 
when it is in its own interests (based on its domestic agenda) (Schmitter 2007). The emergence of centralised decision making and the pooling of sovereignty emerges as a rational act by states as they seek to strengthen the credibility of inter-state commitments and also aid dispute resolution (Börzel 2013).

One evident rationale for co-operative territoriality is for the state (especially smaller, less powerful ones) to utilise regional forces to support/enhance state geostrategy. Axline (1994) notes that regionalism is an adjunct to state strategy where it is used as a means to supplement, support and enhance state power. In this context, regionalism is about the state - through the regional system - acquiring a competency to adapt to globalism; it is through the region that the state can better adapt to global interdependencies (Hettne and Söderbaum 1998, 2000). This can possibly reflect security concerns and a feeling of vulnerability in the presence of global/regional hegemons (Buzan and Waever 2003, Börzel 2013). The logic of regionalism as a commercial strategy for state competition has been more widely accepted (Palan et al. 2001). In this context, smaller states see the benefit of regionalism, with economic integration offering the capability to scale up markets to increase power in a geostrategic sense.

These themes were also evident within the shift towards 'new regionalism'. With this trend, regionalism began to take on a more geostrategic slant as it became less about the region looking inwards and more about utilising regionalism as a tool for participating states to attain influence in the global system (Hettne 2005). In short, the regionalism process became more about the economic interests of the state - though some blocs have evolved to have a strong security focus. However, what is increasingly common is that states are choosing to selectively (in many cases) promote the erosion of national borders to promote territorial seamlessness (Söderbaum 2012).

Much of the literature on regionalism focuses on the formal processes, where power is proactively ceded to supranational/international organisations based on multi-state co-operation. Alongside these formal processes are informal mechanisms between states (Hurrell 1995). In this context, informal integration can reflect everyday cross-border non-state actor interactions that stand outside any formal agreement (such as business networks especially where there are diasporas) (see Kurian 2004). Such informality can also reflect bilateral and multilateral agreements that stand apart from any formal integration process and where the process is explicitly co-operative, with no intent to transfer any powers to 
a supranational entity (Börzel 2016). It is the intensity of these informal cross-border interactions that is seen as one of the more powerful drivers towards the legitimisation of formal integration as states seek to embrace rather than restrict such interactions. These processes underscore the complexity of regionalism where parallel formal and informal process can coexist, especially where common problems are 'localised' or bilateral and not relevant to third states. This informality of integration can reflect a more pragmatic localised solution to common problems on an issue-by-issue basis. The complexity of regionalism is underlined by the fact that some regional agreements have established supranational bodies that are designed to be informal to allow consensus, flexibility and non-confrontation (Heeg and Ossenbrügge 2002, Acharya and Johnston 2007). Wissel (2014) argues that regionalism does not cause inter-state differentials to vanish, and nor does rivalry cease: states still have divergent interests. As such, regional blocs are still very fragmented - something that can only increase as they expand their membership and as their degree of heterogeneity expands as a consequence. Such emergent divergences can limit areas of mutual beneficial co-operation and constrain the efficacy of state strategies that have embedded co-operative territoriality.

\section{THE TERRITORIAL STATE AND ITS INFRASTRUCTURE SYSTEM}

As Bridge et al. (2018) identify, infrastructures are 'the open and closed veins of territory' (p. 3). The infrastructuring process represents a means of enabling state strategy though the creation and maintenance of territory-wide physical networked systems that facilitate the transmission, storage, processing and distribution of tangibles and intangibles within and between territories to support their functioning (Finger et al. 2005, Larkin 2013). Through the generation and management of intra-territorial flows, the state is able to penetrate space to secure its territoriality (Mann 1984, Van der Vleuten 2004). In practical terms, this requires that infrastructure is embedded (to the point of invisibility at the point of usage) into socio-economic systems and that it enables 'valuable' relationships between users creating communities of practice (Star and Ruhleder 1996). The notion of value in infrastructure systems also highlights that they are only effective as a tool of state strategy insofar as a user intends to use that infrastructure (Edwards 2003). Thus universal provision does not mean it is useful to every citizen within a territorial state. In systemic terms, the value of any single component of an infra- 
structure system operates as part of a larger system where a failure of any single component can create cascade effects elsewhere within the territorial system. Such vulnerabilities have focused states on issues of criticality where such cascade effects could challenge state territoriality (Rinaldi et al. 2001). The link between infrastructure and state territoriality does offer an evident rationalisation for the position of authors such as Larkin (2013) who argue that the notion of an embedded NIS can make little sense when the state can use it as an expression of power and legitimacy and offer a means of discourse within its population (see Turner 2020). As a means of reinforcing its territoriality, the state has an incentive to pursue what Larkin terms 'suprastructures'. These are those components of the NIS that are intentionally not embedded within systems but whose existence is made explicit to users.

The NIS represents the totality of the networked infrastructures located within the territorial state. The systemic nature of the NIS underscores that it is more than just the sum of infrastructure located within the borders of a state. For simplicity, the NIS is sub-divided into differing types of infrastructure (Turner 2020): economic infrastructures (that is those that facilitate the flow of economic products/processes within a territory); and enabling infrastructures (those social and institutional structures and systems that enable the effective operation of economic infrastructure) (Howe et al. 2016). Whilst much of the focus within the NIS has been upon the physical economic infrastructures (as indeed reflected within the structure of this book), there has been - over time - an increased focus upon soft infrastructure systems (Niskanen 1991). These soft infrastructure components represent a core enabler of economic infrastructure through the provision of institutional systems for the establishment, usage and evolution of the NIS (Turner 2020). The salience of soft infrastructure has increased within its spatial and operational complexity as well as in diversity of ownership. As the NIS becomes more polycentric - both in terms of ownership of its components and sources and destination of flows - so there has been an increased policy focus upon ensuring that such complexity does not come at the price of system functionality, especially with regard to critical infrastructures (see below). Indeed, as noted below, the need to harmonise soft infrastructure between states is arguably the most salient impact of the development of regional systems. These emergent rules - arising from more complex NIS - are complemented by longstanding soft issues in infrastructure systems formed by the need to ensure that user behaviour is compliant with the territorial needs of the system (Turner 2020). 
According to Mann's notion of state power, states depend on extensive infrastructure systems that allow them to universally penetrate, secure and bind territory as well as create the conditions for economic growth and development (Mann 1984). The interface between state strategy and the NIS is reflected within the infrastructural mandate and underlines the multiple functions of infrastructure in enabling state territoriality (Turner and Johnson 2017, Turner 2018). Briefly these are:

- Control: an extensively developed infrastructure system allows the state to penetrate civil society through its ability to generate and move resources (both tangible and intangible) around a territory. Through such penetration the state is able to exercise ideological, economic, military and political control (Mann 1997).

- Security: as the guarantor of security, one of the main functions of the state is guarding the NIS against external disruption and in utilising infrastructural gateways to exclude illegal/illicit flows (Gilpin 2011). This underlines that the state has the right to vet the de- and re-territorialisation of flows.

- Integration: there is an expectation that the services offered by the NIS are reliable, affordable and of high quality, and that these characteristics are universal across both physically remote or peripheral regions and those areas (both urban and rural) where there is social, political and economic exclusion.This notion of infrastructure as a tool of territorial integration has found a high-profile expression within the 'modern infrastructural ideal' (Marvin and Graham 2001).

- Development/growth: the state of the NIS is important in influencing growth through promoting the efficient circulation of resources (see for example Canning and Pedroni 2004). This should enhance productivity and aid the spread of knowledge within an economy (Martin and Rogers 1995, Estache 2010). Alongside this NIS are also configured to support international interaction between states.

- Sustainability: the development and utilisation of the NIS should be 'efficient' in its use of natural resources (World Bank 2012). There is an expectation that infrastructure systems should be structured and operate in a manner that does not harm the social, economic and ecological processes necessary to facilitate and sustain human equity, diversity and the functionality of natural systems (Dasgupta and Tam 2005). This seeks to decouple (at least in relative terms) infrastructure development and usage from environmental degradation (see Hickel and Callis 2019). 
These drivers of infrastructuring within states were formed against a backdrop of what Schipper and Van der Vleuten (2008) term 'infrastructure nationalism'. This was a period throughout most of the 20th century where there was a pattern of national preference (if not outright discrimination) within NIS. Often this meant that core (critical) economic infrastructures came under state (frequently monopoly) ownership based on a desire to ensure that these developed in a manner that supported and enabled state territorial strategy. This pushed themes of universal access, state control and cohesion to the fore, with states often financing NIS development through a mix of user charges and taxation. This was supported by national preference in procurement and standardisation. Inevitably, this strategy of infrastructure nationalism promoted systemic fragmentation, though not outright isolation as it did not preclude NIS interconnection; it was just not a priority. Whilst states would not want to promote spillover between systems (where one state could benefit from another's infrastructure investment) there was an acceptance of the need to facilitate interconnections between NIS due to economic and social flows between these systems. However such flows would face the bottlenecks created by the existence and probable underdevelopment of border infrastructure where state infrastructuring exists to undertake the simultaneous (and seemingly contradictory) acts of facilitating, monitoring and filtering the de- and re-territorialisation of flows.

\section{REGIONAL INFRASTRUCTURING AND CO-OPERATIVE TERRITORIALITY}

As a strategy of co-operative territoriality, regional infrastructure systems (RIS) are rationalised on the basis of states seeking to integrate national systems so as to increase the velocity, efficiency and penetration of flows from partner states so as to reinforce (or, at the very least, not compromise) the infrastructural mandate (see Table 1.1). In this context, RIS are based on the fixed national infrastructures that are produced, reconfigured, re-differentiated and transformed to enable accelerated and expanded movement that accompanies regionalism (Brenner 1999). Such regional processes impact (both directly and indirectly) upon each of the identifiable properties of infrastructure (see Table 1.2). These impacts reflect that RIS emerge out of retrofitting the respective NIS to its shifting context to create a network of national networks where flows are rendered seamless by expanding capacity and/or removing frontier/ border infrastructure (where necessary) and co-ordinating/harmonising 
soft infrastructure (Howe et al. 2016). Inevitably, balancing a desire for the largely economic benefits from the increased velocitisation of cross-border flows has to be reconciled with the need for bordering and filtering to ensure state security and control (Harvey 1985). This means discriminatory filtering by states between partners and non-partner states at the region's borders, creating pressure to establish a network of hard and mutually supporting soft infrastructure systems between states (Van der Vleuten 2004, Turner 2018). Border infrastructure tends to defy the convention that infrastructure should disappear into the background and be transparent in usage (Star 1999). Border infrastructure is an expression of state power and is designed to be a visible expression of that power (Larkin 2013). This reflects what Turner (2020) terms the process of suprastructuring so as to support territoriality.

\section{Table 1.1 Regionalism and infrastructure mandate}

\begin{tabular}{ll}
\hline $\begin{array}{l}\text { Component of } \\
\text { Infrastructural Mandate }\end{array}$ & Example of Regional Dimension \\
\hline Control & $\begin{array}{l}\text { This can be shaped by cross-border flows of people and ideas, } \\
\text { especially where ethnic groups straddle border areas. There is a need } \\
\text { for states to monitor flows to the extent that external borders are } \\
\text { policed so as not trade off economic interaction without comprising } \\
\text { control of any single state within the group. This may also require } \\
\text { police co-ordination and cooperation. } \\
\text { The erosion of internal borders will need to be replaced by external } \\
\text { borders at the region's edge. The common concern is based on } \\
\text { consensus between states as to the nature of any external threat. } \\
\text { To promote social and economic cohesion so that any flows between } \\
\text { states do not destabilise any single state or region within any state. The } \\
\text { process must also militate against any threat to social cohesion of any } \\
\text { group within the region. } \\
\text { The state seeks the growth of easier trade and investment between } \\
\text { states within the region in the expectation that it will benefit economic } \\
\text { growth and/or development. } \\
\text { Integration of economic systems renders resource efficiency in the use } \\
\text { of infrastructures (or a component of) an issue of collective concern. }\end{array}$ \\
\hline Growth &
\end{tabular}

Regional infrastructuring as a form of cooperative territoriality has to reflect that co-operation between states can militate against conflicts and inconsistencies between the respective members of the regional grouping 
as well as operating (as mentioned) as a platform for the solution of common problems. As such, at the core of the development has to be that the respective NIS are at similar stages of development, and that soft infrastructure components can be approximated. Beyond this, states must see a mutual benefit from the integration of NIS, possibly from the perception that cross-border economic interactions are either stymied or under-developed from the absence of interconnection. In some cases, it could be that landlocked states require regional systems to aid fuller integration into regional systems as a precursor to fuller integration into the global system. Importantly these efforts must also be supported by uniformity over the commonality of state strategy with regard to notions of security, economic development with further approximation of the control objectives that allow co-operation between respective civil units. This also reinforces the aforementioned point that co-operative territoriality has to be supported by trust between partners, especially with regard to the mutual legitimisation of flows.

Whilst regionalism as co-operative territoriality is seen as a pragmatic strategy to reinforce state territorial strategy in a complex international system, there are aspects (especially with regard to the territorial role of NIS) where the process can operate as a constraint upon its effectiveness as a tool of territorial strategy (especially with regard to state security). The immediate impact of regionalism in infrastructural terms is the erosion of the importance of aforementioned border infrastructure and lowering their ability to operate as filters and points of control to ensure state security. As mentioned, the logic of regionalism is to remove (or at least reduce) such impediments and increase capacity either side of the border to capture the benefits of lower transaction costs associated with freer flows between these territories (Sohn 2014). This views the removal of border infrastructure through a neo-liberal lens of trade liberalisation though broader economic, social and political processes can be at work in this process. In some cases the border is an artificial barrier that inhibits longstanding socio-economic interactions.

There are cases where extra-territorial infrastructure can represent a potential territorial challenge when it becomes a 'choke point' within the international system and where any disruption to this 'hub' has cascade effects on a number of NIS. Where such choke points are regional in nature or are a common concern for a group of states, co-operation is a rational strategy. Such decisions are also rationalised where - in an international system of flows - agents other than the state can penetrate and gain legitimacy within its civil society. This is especially salient 
where infrastructure relations cannot be demarcated to the borders of the state (Glassman 1999, Painter 2010). Where such relations are part of international value chains (or other such pan-national configurations) then infrastructures lose their sense of 'pure' nationality as they operate as part of a larger socio-economic space (Sassen 2013).

\section{Table 1.2 Infrastructure properties and the tensions of regionalism}

\begin{tabular}{|c|c|}
\hline Infrastructural Property & Impact of Regionalism in Infrastructure System \\
\hline Embeddedness & $\begin{array}{l}\text { The process implies that national systems become in operational terms } \\
\text { indistinguishable from one another and that such differences as there } \\
\text { are become invisible. }\end{array}$ \\
\hline Transparency & $\begin{array}{l}\text { When a user moves from one NIS to another there is no adaptation to be } \\
\text { made by users in terms of behaviour and terms and form of use. }\end{array}$ \\
\hline Reach or scope & $\begin{array}{l}\text { A single piece of territorial infrastructure has the potential to have } \\
\text { extra-territorial effects should its operation be either enhanced or } \\
\text { disrupted. }\end{array}$ \\
\hline $\begin{array}{l}\text { Learned as part of } \\
\text { membership }\end{array}$ & $\begin{array}{l}\text { The norms and processes of moving between systems creates learning } \\
\text { processes as users develop common understandings of cross-border } \\
\text { mobility and of utilising seamless but differentiated NIS. }\end{array}$ \\
\hline $\begin{array}{l}\text { Links with conventions } \\
\text { of practice }\end{array}$ & $\begin{array}{l}\text { Movement between national systems requires an understanding of } \\
\text { mutually agreed conventions with regard to usage. Whilst conventions } \\
\text { of usage can reflect a system's history and pattern of evolution, such } \\
\text { differences do not inhibit seamless/relative ease of movement within } \\
\text { and between systems. }\end{array}$ \\
\hline $\begin{array}{l}\text { Embodiment of } \\
\text { standards }\end{array}$ & $\begin{array}{l}\text { To ensure mutual recognition of conventions, embeddedness and } \\
\text { transparency, systems agree common (mutually agreed) standards } \\
\text { allowing each NIS to interoperate without the need for regular policing/ } \\
\text { regulation of non-domestic sourced flows. }\end{array}$ \\
\hline Built on an installed base & $\begin{array}{l}\text { The regional system builds upon the processes and physical systems of } \\
\text { pre-existing national and international systems. }\end{array}$ \\
\hline $\begin{array}{l}\text { Becomes visible upon } \\
\text { breakdown }\end{array}$ & $\begin{array}{l}\text { In operational terms, the national system (or a part thereof) only } \\
\text { becomes visible once it either fails or begins to act as an impediment to } \\
\text { seamless international flows. Such visibility can be driven by human, } \\
\text { technical or natural factors. }\end{array}$ \\
\hline $\begin{array}{l}\text { Is fixed in modular } \\
\text { increments, not all at } \\
\text { once or globally }\end{array}$ & $\begin{array}{l}\text { Whilst any component of any national system has some degree } \\
\text { of regionalism, its maintenance and development are undertaken } \\
\text { on a piecemeal basis such that the system improves/develops } \\
\text { incrementally, potentially creating uneven patterns of infrastructure } \\
\text { evolution across the regional system. }\end{array}$ \\
\hline
\end{tabular}


This means that states need to adapt to the process of regionalism through the production, re-configuration, re-differentiation and transformation of NIS across contiguous and semi-contiguous space (Brenner 1999). The result is that RIS emerge as a complex amalgam of NIS based upon inter-state co-operation to reflect the respective interests of the component parts. Despite such adaptive tensions created by the shift in infrastructural relations, the larger system is still state-based as a source, destination or transit of flows through the regional system (Keating 2013). This reflects the absence of regional territoriality due to states being unwilling to cede many of their competences to supranational bodies (Murphy 2013). Thus the regional system emerges out of state needs, with supranationality (at best) being limited to stimulating inter-state co-ordination to militate inconsistences and gaps between NIS rather than directly facilitating a de facto regional system (Turner 2018). Co-operation between states reflects commonality of interest and the intentional absence of a higher regional body.

As such, regional infrastructuring will reflect co-operative territoriality on two processes. The first is the promotion of a virtual regional system via the interworking, interoperation and interconnection of separate national systems. This will focus on aligning soft infrastructure systems, increasing capacity at key pinch points and on building missing links within the system which (both directly and indirectly) hinder physical flows within the region. The second is co-operation to create single regional infrastructures that operate across multiple contiguous territories. The co-operation is rationalised as these territories are the source, destination and/or place of transit for transnational flows. Despite their inherent transnationality, these systems are still state-dependent as they rely upon state sanction either for transit or the de/re-territorialisation of flows (Table 1.3 reflects a fuller list of the types of re-infrastructuring evidenced). This reflects that - as an adaptive tension - regionalism is placing pressure on NIS to adapt, and is doing so through one or more of the following (Turner 2018):

- Formal regional agreements between states that stimulate increased cross-borders flows;

- Bilateral agreements between states to recognise longstanding interdependence through the interconnection of NIS;

- Global/regional hegemonic pressure may also seek to stimulate closer NIS integration as a means of promoting systemic stability as a reflection of their own political and economic interests; 
- Multi-lateral agreements to build multi-state regional infrastructures.

Whilst this list is not definitive, it is important in that it underlines that regionalism within infrastructure systems is not synonymous with the formal integration process. Indeed (as noted below), in the case of Europe, inter-state (informal) processes of integration have a long and continuing presence in the ongoing regionalisation of NIS across the continent. Thus co-operative territoriality as a state strategy need not be expressed solely within formal integration agreements as states may be unwilling to cede power to supranational bodies even in the presence of common problems, and existing bilateral links may be the more effective method of NIS interconnection. The forms of regional infrastructuring evidenced in Europe are highlighted in Table 1.4.

The salience of co-operative territoriality within and between NIS depends upon the impact of the flows between states. This, in turn, is driven by the type of flow (formal/informal) and the extent to which the erosion of internal regional borders are legitimised, and state confidence in the ability of external regional borders to replace internal filters. Across different regional groupings there are variances as regards the intensity of co-operative territoriality due to variations in the erosion/eradication of internal borders and of the consequent degree of integration of NIS. The erosion of internal borders reflects a belief that bottlenecks are seen as bad for the efficiency of the system without clearly recognising their strategic value to territoriality, especially at borders where the slowing of traffic is necessary as part of the security process.

Underpinning the notion of co-operative territoriality is that the formal integration of infrastructure systems allows states to - at least partially mutualise infrastructure risk. This infrastructure risk has been reflected in themes on criticality. Criticality is defined here as concerning those parts of the NIS whose failure would pose a direct challenge to state territoriality (Turner 2018). Interconnection between NIS means that a local failure within a national system can be - at least in part - mitigated by connectivity with other NIS that allows flows to be sustained into a state, thus minimising disruption. Inevitably this focusses the state upon key pinch points in the system and seeking to develop alternatives to such bottlenecks to erode such vulnerabilities. Through such processes the regional system creates a process of mutual support under scenarios of rising infrastructure risk. The degree of interconnection can also create its own risk where outright integration creates regional infrastructure dependencies that can create a contagion of failure throughout the system 
based on localised issues. As such, co-operative territoriality has to involve managing these spatial interdependencies. The fuller interface between the core requirements of the NIS and the enablement offered by RIS is outlined in Table 1.3.

Table 1.3 The interface between national and regional infrastructure systems

\begin{tabular}{ll}
\hline NIS Facet & Role of Regional System \\
\hline Universality & $\begin{array}{l}\text { The promotion of regional systems has the potential to increase access to } \\
\text { infrastructure services in frontier regions which are often characterised by } \\
\text { infrastructural under-development due to their frequent peripherality to main } \\
\text { centres of state activity and population. }\end{array}$ \\
Connectivity & $\begin{array}{l}\text { The growth of regional connectivity can aid trade across the region as well as } \\
\text { enabling flows between component NIS. }\end{array}$ \\
Globality & $\begin{array}{l}\text { States (especially if landlocked) could use regional systems to access global } \\
\text { logistical channels. These regional links can also be used to generate security of } \\
\text { Supply by enabling access to diverse globally sourced energy. }\end{array}$ \\
& $\begin{array}{l}\text { The risks across respective NIS can be mutualised through the connection of NIS to } \\
\text { allow sustained flows in the presence of local failure. }\end{array}$ \\
& $\begin{array}{l}\text { The promotion of interconnectivity between NIS of differing quality can force } \\
\text { a state with lower-quality systems to upgrade systems to ensure full interoperability. }\end{array}$ \\
& $\begin{array}{l}\text { The interconnection between systems can stimulate states to increase NIS capacity } \\
\text { at key potential pinch points within regional systems. }\end{array}$
\end{tabular}

\section{REGIONALISM AND THE EUROPEAN INFRASTRUCTURE SYSTEM}

Underpinning processes of regionalism within European NIS has been an emergent sense of co-operative territoriality within the European region (Wallace 1999) where aspects of the aforementioned infrastructural mandate (notably growth, cohesion and security (see below)) can be enabled, supported or enhanced by action at the supranational level of governance (see also Table 1.2). This reflects that there is no sense of coherent separate territorial or geo-strategy being developed at the EU level. At best, any notion of EU territoriality is a reflection of inter-state co-operation and co-ordination (Mamadouh 2001, Bialasiewicz et al. 2005, Pullano 2011) with the EU Europeanising state strategy to offer advantages of scale (Perkmann 2007, Vollaard 2009). 
Thus, where there are elements of territorial strategy they are at best shared competences, with supranational action being secondary to state strategy (Walters 2004, Vitale 2011, Faludi 2013). Thus, regionalism as a territorial system is an amalgam of state territoriality, the willingness of states to allow penetration by intra-group flows and the trust by states that the external boundaries of the region can be adequately policed. Consequently the notion of a separate EU-wide regional territoriality above the state is largely illusory as states limit co-operation in terms of scope and scale (Scott 2009). This is also evident in the absence of independent EU geostrategy; though, as the European Infrastructure System (EIS) is embedded within a global network of infrastructures, it has an evident geostrategic dimension (Newman and Paasi, 1998). This geostrategic dimension reflects not just notions of the security and reliability of externally sourced flows (in the absence of internal borders) (Scott and Van Houtum 2009) but also how aspects of the EIS depend upon external infrastructures (and the sustenance of flows through them) for their effectiveness (Carr 2016). To promote this security of flows, EU states co-operate to use their economic power to influence the behaviour of states within its neighbourhood and beyond (Pace 2007, Browning and Joenniemi 2008, Browning 2018). These patterns reflect that the EIS is not a closed infrastructure system, and that part of the logic of integration is to enable all states to interconnect securely with global transmission systems by connecting into those states which have pre-existing access (Schipper and Schot 2011).

Bialasiewicz et al. (2005) suggest that the EU eschews the notion of hard territoriality associated with infrastructuring in favour of an 'aspirational territoriality' that seeks to promote territorial cohesion by creating a space of common values and solidarity. EU narratives surrounding notions of territorial cohesion reflect this approach as this is more about a shared political vision than a 'hard' sense of creating a uniform space (Faludi 2009). This reflects that the notion of 'cohesion' as a common territorial goal has to coexist with the hard territoriality of states (Faludi 2014). This aspirational territoriality has to be agreed and co-ordinated between states to be attained. The EU - the authors argue - is riddled with territorial ambiguities where the EU's ideals run up against an absence of territorialising competences at the supranational level of governance (Bialasiewicz et al. 2005).

These notions of Europe and its aspirational territoriality shape the infrastructuring process within the EU. This is a region of pre-existing systems that have evolved to serve national needs, but where there are 
(or have been) links between these national systems. However across these states the quality, quantity and maturity of NIS can differ markedly. This is also compounded by NIS not always responding to the adaptive tensions placed upon them by regionalism as well as other forces. The aspirational territoriality of the EU has an ideal EIS in mind that enables Europe to operate and function as a cohesive group supporting competitiveness and sustainability whilst not compromising state concerns of security and control. Table 1.4 indicates the numerous forms of infrastructuring that are evident throughout the European system of NIS that lies at the core of the EIS.

\section{Table $1.4 \quad$ Forms of infrastructuring in the European regional system}

\begin{tabular}{|c|c|}
\hline $\begin{array}{l}\text { Infrastructural } \\
\text { Process }\end{array}$ & Description \\
\hline Interconnection & $\begin{array}{l}\text { This process is based on the physical interconnection of pre-existing } \\
\text { systems by the establishment and maintenance of physical links between } \\
\text { NIS to support the reliability, resilience, security, consistency and/or } \\
\text { predictability of flows between states. }\end{array}$ \\
\hline Interoperability & $\begin{array}{l}\text { This process seeks to ensure that flows between NIS are rendered seamless } \\
\text { through the adoption of common standards and protocols so as to allow } \\
\text { national systems to interwork. }\end{array}$ \\
\hline Transit & $\begin{array}{l}\text { Parts of the regional system are needed to ensure flows between } \\
\text { non-contiguous states. These systems are required not merely for the } \\
\text { benefit of the state in which the transit infrastructure is located but because } \\
\text { without it flows across the wider region could face bottlenecks or long } \\
\text { diversionary routes. }\end{array}$ \\
\hline $\begin{array}{l}\text { Regional by Design } \\
\text { Systems }\end{array}$ & $\begin{array}{l}\text { These are dedicated systems that cross multiple territories. They are } \\
\text { designed to promote pan-regional flows where there is a regional } \\
\text { dislocation between flow source and destination and where existing } \\
\text { national systems are inadequate or not for the nature of the flow. }\end{array}$ \\
\hline De-infrastructuring & $\begin{array}{l}\text { The ease of flows across borders requires the removal of those border } \\
\text { infrastructures that seek to operate as checks and bottlenecks within the } \\
\text { regional system. }\end{array}$ \\
\hline Re-infrastructuring & $\begin{array}{l}\text { These are parts of the system that need to be re-purposed as a result of } \\
\text { regionalism. They are infrastructures built to serve national needs but } \\
\text { which now operate as key hubs/links within the regional system. This may } \\
\text { mean an increase in capacity or adaptation to new standards/protocols. }\end{array}$ \\
\hline
\end{tabular}


Contextualising regional infrastructuring as a largely state-driven phenomenon shaped by an ongoing process of both formal and informal integration underscores the variety of measures that promote infrastructural integration across Europe (Opitz and Tellmann 2015). The EIS is defined here as the totality of interacting and mutually dependent networked national and transnational infrastructure within the geographic space of Europe (Turner 2018). This conceptualisation of the EIS (as suggested above) sees it as a regional network of networks built from the state-based system (Van der Vleuten and Kaijser 2005). Indeed Misa and Schot (2005) see the process as long term, referring to hidden integration of European infrastructural integration as inter-state agreement, and disagreement has led to a successive linking and delinking of infrastructures. Such state-based processes became subsumed within supranational initiatives - notably the Trans-European Networks (TENs) programme (see below), which has contextualised bi- and multilateral initiatives within the context of a broader supranational strategy (Dülffer 2009). Overall, the development of the EIS involves multiple levels of governance.

\section{Inter-State Processes}

As will be mentioned throughout, the development of the EIS is largely a state-based process formed around a series of bilateral and multilateral interconnections. In a continent with a high degree of state-based territorial fragmentation, inter-state collaboration is normal across both soft and hard aspects of NIS (Van der Vleuten and Kaijser 2005, Badenoch and Fickers 2010). Such actions reflect a long history of infrastructural integration, much of which pre-dates (by about a century) both the current territorial configuration and the push towards supranationality within the system (Johnson and Turner 1997, 2007, Van der Vleuten and Kaijser 2006). The integration of both hard and soft systems form the basis of the European-wide system - a process driven by the rational actions of states as they seek to manage the overlap between territorial and geo-strategies (Darian-Smith 1999). Transnational infrastructures were - and are - the norm across Europe by strategic intent, with the international dimension of the NIS being an inevitable component in system development and design (Badenoch and Fickers 2010). Such strategies did not inhibit states pursuing their own interests in the development of their respective NIS. Sometimes this was in isolation, with the result of emerging incompatibilities between systems which have only been rendered interoperable retrospectively. The most evident legacy of this long-term 
trend is that discretionary supranational action is largely unnecessary as states can develop the EIS in a piecemeal fashion operating in their own interests (Schipper and van den Vleuten 2008, Högselius et al. 2013).

Alongside these multiple bilateral interconnections are multilateral infrastructures based upon the interconnection and/or traversing of three or more states. Such infrastructures reflect the need for security of flows by either a single state (where, for example, it is landlocked and requires such systems to access global logistical systems) or where such systems are necessary to transport flows across and to multiple states driven by spatial disparities in the availability of resources (Walters 2004). In the former, this is a process of interconnecting, multiple national systems to create pan-European mobility by lowering the transaction costs associated with fragmented and/or isolated NIS. In the latter, there is dedicated pan-European infrastructure to securely transport flows across and between multiple states (Kandiyoti 2012).

Whilst infrastructure nationalism (Schipper and Van der Vleuten 2008) was the predominant model of infrastructure development throughout Europe in the 20th century this did not remove tensions to seek to interconnect or even integrate these national systems. Throughout this period, there were a number of initiatives, not necessarily to counter infrastructural nationalism but to ensure that this process did not 'Balkanise' the European system. Thus there was US pressure to integrate systems as part of post-war reconstruction and, alongside, these assorted Europe-wide co-operative forums emerged to promote continent-wide inter-NIS interoperability (see below).

\section{International Initiatives}

Before the EU gained competences for the creation of single markets for the various network services provided over the EIS, there were and remain longstanding international agreements and organisations between states to ensure interoperability between national systems. Some of these reflect the fact that certain networks pre-dated the current territorial configuration of Europe and that there needed to be agreement on interworking of national systems. The International Union of Railways/Union internationale des chemins de fer (UIC) was established in 1922 to standardise practices and to limit any fragmentation of the European rail system. Its remit included a revenue-sharing agreement between respective national systems based on a 'UIC code' that defines rules and best practice. These rules now operate globally, though much of the EU-based standards 
work is now done by the European Rail Agency. Similar inter-state agencies exist in telecommunications, where the European Conference of Postal and Telecommunications Administrations (CEPT) - established in 1959 - exists to develop agreed standards in telecommunications across technical, operational, regulatory and commercial issues as does the International Telecommunications Union (ITU). There are also standardisation organisations in the energy sector, with the European Committee for Electrotechnical Standardization/Comité Européen de Normalisation Électrotechnique (CENELEC) covering the evolving European electricity system and gas through the European Committee for Standardization/ Comité Européen de Normalisation (CEN). These have more latterly been supported by operator-driven initiatives through the European Network of Transmission System Operators for Gas (ENTSO-G) and the European Network of Transmission System Operators (ENTSO-E), both of which have a standardisation and network integration mandate (see Chapter 3).

In practice, there are a range of co-operative agreements between states and national and international operators, as well as other stakeholders, to develop national networks in a manner that renders them both interconnectable and interoperable. These inter-state/interoperator co-operative arrangements reflect both longstanding and emergent interdependencies that pre-dated the formal integration process and/or have emerged as a response to it. In some cases, the process was driven not only by a desire to sustain interconnectivity against a fragmenting territorial system but also to facilitate integrated systems for emergent infrastructures in a post-war environment. The creation and sustenance of such co-operative frameworks underpins the arguments of Van der Vleuten and Kaijser (2005) that - in many cases - co-ordinated supranational action is rendered unnecessary.

\section{Supranational Initiatives}

Whilst there have been a number of sectoral policies at the supranational level on the respective economic infrastructure sectors, the Trans-European Networks (TENs) programme was the first attempt to give the EIS a more systemic treatment (Johnson and Turner 2007). Launched in 1990 and contextualised by the emergence of the Single European Market (SEM), which exposed the inadequacies of the prevailing infrastructure system, TENs formalised many bilateral and multilateral programmes within a single strategy for European infrastructuring 
(Johnson and Turner 1997). This single strategy sought to reinforce and add impetus to pre-existing processes as well as stimulating new structures to promote more widely developed systemic interconnection, interoperability and access through the framework of open and competitive markets. This process represented an attempt to undertake a geostrategic infrastructuring of the EIS as a means of using the scaling up of infrastructure systems to EU-wide level as a platform for exercising its geo-economic and geopolitical power. However, these processes were still largely state-led, with the EU limited to a largely marginal role in facilitating trans-European mobility by promoting border infrastructure capacity, better infrastructure services and socio-economic cohesion (Johnson and Turner 1997).

For states, TENs as a policy strategy was legitimised by a desire to co-operate to promote secure supplies of essential products, facilitating trade and lowering investment costs. Consequently, the importance of TENs lies more in its role as a catalyst for state-led development, highlighting systemic deficiencies, missing links, uneven maturity of systems and soft infrastructure requirements of the EIS (Johnson and Turner 1997). In this context, TENs emerges as an attempt to reconcile state overlap between territorial and geo-strategies to co-ordinate infrastructural integration. That infrastructuring remains a state-based competence reflects the aforementioned absence of a sense of European territoriality, and that the erosion of internal borders requires states to address gaps within and between their respective NIS (Mamadouh 2001, Bartolini 2005). Thus TENs as a policy strategy operates within the context of state-based infrastructuring strategies with the EU having very little discretion.

For the EU, TENs are justified on the basis that the failure of an overarching body to act would lead to the under-provision of cross-border infrastructure, with the EIS tending towards fragmentation and sub-optimal operation conditions due to this absence of co-operation and scale (Vaubel and Willet 1991). For the EU, only a supranational body can do this; though, as suggested above, states have tended to be more pragmatic than strategic in establishing cross-border links. For the EU, as a forum for co-ordination, it is the most appropriate body to realise network effects throughout the EIS. Connectivity to attain network effects is the prime strategic objective of the integrative elements behind TENs. This means not just the existence of a link to all parts of Europe, but that the link has sufficient capacity in that it promotes intra-regional economic convergence. 
Whilst the plan laid the basis for a common infrastructure policy, it was in retrospect a policy of very limited efficacy. This was largely due to the large funding gaps within many of the projects (especially transport and energy), driven by the programme's reliance on state finance for its realisation (see Chapters 2 and 3). Throughout its evolution as a policy programme there were numerous attempts by the European Commission to establish less state dependency in project finance (see Johnson and Turner 1997, 2007). However this was always resisted by states and it was only in information infrastructures that significant sources of non-state finance were available (see Chapter 4). The main source of EU finance for TENs projects is currently (2021) through the Connecting Europe Facility (CEF), which only provides very limited financial support for the development of priority projects. The European Investment Bank (EIB) can also offer support, though this is less through direct grants and more through seeking to arrange the desired levels of funding from the financial markets.

However, as noted above, the EU is not the only option for the development of an EIS. In some areas, states preferred to co-operate outside of supranational frameworks that some considered too restrictive. The development of TENs as a distinct public policy area built upon existing co-operative frameworks, often bypassing or replacing longer-standing international bodies involved in establishing transnational interoperability and interconnection. The result has been a rather muddled framework of co-operative bodies shaping the evolving EIS.

Arguably a greater impact of the EU (alongside pre-existing intergovernmental bodies on issues such as standards) has been in the area of soft infrastructure. These will be examined in more detail in the respective chapters; but - both in a generic and a sectoral sense - the EU has (through its impact on soft infrastructure) proved a proactive body in facilitating the integration of NIS. The development of the SEM programme, with its elimination of internal borders, necessitated the creation of institutional frameworks to ensure that this did not compromise state control or security (see Chapter 2). This builds on longstanding common policies in the economic infrastructure sectors, notably transport and energy, which also focused on soft infrastructure in promoting interoperability and liberalisation of national systems. These policies did little more than seek to co-ordinate national policies to promote sectoral rather than infrastructural integration.

The EU has also started to become more proactive with regard to the co-ordination of member states' critical infrastructure with its focus on 
those national infrastructures whose failure would impact upon two or more states (Pursiainen 2009). This reflects a desire to mitigate cascade effects within the EIS via co-operation between states and in setting agreed standards of resilience (Burgess 2007). This strategy seeks to ensure that common threats (even if the impacts are local) do not fragment the system (Hämmerli and Renda 2010). However, power remains with the states that have shown they are willing to suspend regional flows if their territoriality is threatened. Many states are resorting to inter-state agreement rather than using supranational systems which tend to merely offer an awareness of the opportunities of collaboration and the spreading of best practice. Van der Vleuten et al. (2013) argue that longstanding collaboration between states negates the need for any supranationality, especially as a decentralised system tends to work well (see also Van der Vleuten and Lagendijk 2010). This reflects a longstanding process of 'hidden' integration that lies outside of the EU's institutional structure.

\section{CONCLUSION}

Whilst the development of the EIS involves a multiplicity of actions at multiple levels, it is the states that ultimately drive its development. This is based on a rational act by states that want to secure and enhance their territoriality. The evident overlap between a state's territorial and geo-strategies reflects an adaptive tension to which states are responding. This they do via a strategy of cooperative territoriality. Regionalism as an adaptive tension places pressure on states to adapt NIS to ensure that territorial strategy and geo-strategies are aligned to support state territoriality. In Europe, such interconnections reflect longstanding links between states. These links have been increasingly integrated into the formal integration process through the EU's Trans-European Networks initiative.

\section{NOTES}

1 Formal integration refers to those measures to promote integration that are encapsulated within state-led, policy-driven programmes. Informal integration involves those 'everyday' flows (both official and unofficial) of capital, products and people between states by non-state actors that are of an intensity that generates some degree of interdependence.

2 Readers interested in his aspect of the process of European infrastructuring should consult the volume edited by Van der Vleuten and Kaijser (2006).

3 The region here is viewed through the lens of IPE, and as such is treated as a supranational subsystem of the international system based upon a number 
of clustered states drawn together by interdependence across a usually contiguous or semi-contiguous space (Hettne and Söderbaum 2000, Hettne 2005).

4 Smith (1992) stresses that regionalism varies between groups according to its scope (the array of policy issues included in agreement), depth (the degree of uniformity of policy actions), institutionalisation (the degree of formal building of common institutional systems) and centralisation (the extent to which centralisation of authority is pursued).

\section{REFERENCES}

Acharya, A., and Johnston, A. I. (eds) (2007). Crafting cooperation: Regional international institutions in comparative perspective. Cambridge: Cambridge University Press.

Agnew, J. (1994). The territorial trap: The geographical assumptions of international relations theory. Review of International Political Economy, Vol. 1, No. 1, pp. 53-80.

Agnew, J. (2000), Global political geography beyond geopolitics, International Studies Review, Vol. 2, No. 1, pp. 91-99.

Agnew, J. (2005). Sovereignty regimes: Territoriality and state authority in contemporary world politics. Annals of the Association of American Geographers, Vol. 95, No. 2, pp. 437-461.

Arrighi, G. (1994). The long twentieth century: Money, power, and the origins of our times. London: Verso.

Auster, R., and Silver, M. (1979). The state as a firm: Economic forces in political development. Boston, MA: Martinus Nijhoff.

Axelrod, R. (1984). The evolution of cooperation. New York: Basic Books.

Axline, A. W. (ed.) (1994). The political economy of regional cooperation: Comparative case studies. London: Pinter.

Badenoch, A., and Fickers, A. (eds) (2010). Materializing Europe: Transnational infrastructures and the project of Europe. Basingstoke: Palgrave Macmillan.

Bartolini, S. (2005). Restructuring Europe: Centre formation, system building, and political structuring between the nation state and the European Union. Oxford: Oxford University Press.

Bialasiewicz, L., Elden, S., and Painter, J. (2005). The constitution of EU territory. Comparative European Politics, Vol. 3, pp. 333-363.

Börzel, T. A. (2013). Comparative regionalism: European integration and beyond. In Carlsnaes, W., Risse, T., and Simmons, B. A. (eds), Handbook of international relations. London: Sage, pp. 503-530.

Börzel, T. A. (2016). Theorizing regionalism. In Börzel, T. and Risse, T. (eds), The Oxford handbook of comparative regionalism. Oxford: Oxford University Press, pp. 41-63.

Brenner, N. (1999). Beyond state-centrism? Space, territoriality, and geographical scale in globalization studies. Theory and Society, Vol. 28, No. 1, pp. 39-78. 
Bridge, G., Özkaynak, B., and Turhan, E. (2018). Energy infrastructure and the fate of the nation: Introduction to special issue. Energy Research and Social Science, Vol. 41, pp. 1-11.

Browning, C. S. (2018). Geostrategies, geopolitics and ontological security in the Eastern neighbourhood: The European Union and the 'new cold war'. Political Geography, Vol. 62, pp. 106-115.

Browning, C. S., and Joenniemi, P. (2008). Geostrategies of the European neighbourhood policy. European Journal of International Relations, Vol. 14, No. 3, pp. 519-551.

Burgess, J.-P. (2007). Social values and material threat: The European programme for critical infrastructure protection. International Journal of Critical Infrastructures, Vol. 3, No. 3-4, pp. 471-88.

Buzan, B., and Waever, O. (2003). Regions and powers: The structure of international security. Cambridge: Cambridge University Press.

Canning, D., and Pedroni, P. (2004). The effect of infrastructure on long run economic growth. Harvard University Working Paper, Vol. 99, No. 9, pp. 1-30.

Carpenter, M. J. (2019). Understanding aterritorial borders through a BIG reading of Agnew's Globalization and Sovereignty. Borders in Globalization Review, Vol. 1, No. 1, pp. 123-126.

Carr, M. (2016). Fortress Europe: Dispatches from a gated continent. London: New Press,

Cerny, P. G (1995). Globalisation and the changing logic of collective action. International Organization, Vol. 49, No. 4, pp. 595-625.

Cerny, P. G. (2010). The competition state today: From raison d'état to raison du monde. Policy Studies, Vol. 31, No. 1, pp. 5-21.

Cini, M. (ed.) (2003). European Union politics. Oxford: Oxford University Press.

Cini, M. (2010). Intergovernmentalism. In Cini, M. and Borragán, N. P.-S. (eds), European Union politics (3rd edn). Oxford: Oxford University Press, pp. 86-104.

Darian-Smith, E. (1999). Bridging divides: The Channel Tunnel and English legal identity in the new Europe. Oakland: University of California Press.

Dasgupta, S., and Tam, E. K. (2005). Indicators and framework for assessing sustainable infrastructure. Canadian Journal of Civil Engineering, Vol. 32, No. 1, pp. 30-44.

Dehousse, R., Weiler, J. H. H., and Wallace, W. (1990). The dynamics of European integration. London: Pinter.

Dülffer, J. (2009). The history of European integration: From integration history to the history of integrated Europe. In Loth, W. (ed.), Experiencing Europe. Baden-Baden: Nomos, pp. 17-32.

Edwards, P. N. (2003). Infrastructure and modernity: Force, time, and social organization in the history of sociotechnical systems. In Misa, T. J., Brey, P., and Feenberg, A. (eds), Modernity and technology. Cambridge, MA: MIT Press, pp. 185-226.

Estache, A. (2010). Infrastructure finance in developing countries: An overview. EIB Papers, Vol. 15, No. 2, pp. 60-88.

Faludi, A. (2009). Territorial cohesion under the looking glass: Synthesis paper about the history of the concept and policy background to territorial cohesion. 
European Commission, Regional Policy, Inforegio. Available at http://ec .europa.eu/regional_policy/consultation/terco; date accessed 25/11/2020.

Faludi, A. (2013). Territorial cohesion, territorialism, territoriality, and soft planning: A critical review. Environment and Planning A: Economy and Space, Vol. 45, No. 6, pp. 1302-1317.

Faludi, A. (2014). Territorial cohesion beyond state territoriality. In CIST2014: Fronts et frontières des sciences $d u$ territoire/Frontiers and boundaries of territorial sciences. Proceedings du 2e colloque international, 27-28 March 2014. Paris: Collège international des sciences du territoire, pp. 179-183.

Finger, M., Groenewegen, J., and Künneke, R. (2005). The quest for coherence between institutions and technologies in infrastructures. Competition and Regulation in Network Industries, Vol. 6, No. 4, pp. 227-259.

Fukuyama, F. (2004). Statebuilding: Governance and world order in the 21st century. New York: Cornell University Press.

Giddens, A. (1985). The nation-state and violence. Los Angeles: University of California Press.

Gilpin, R. (2011). Global political economy: Understanding the international economic order. Princeton, NJ: Princeton University Press.

Glassman, J. (1999). State power beyond the 'territorial trap': The internationalization of the state. Political Geography, Vol. 18, No. 6, pp. 669-696.

Gritsch, M. (2005). The nation-state and economic globalization: Soft geo-politics and increased state autonomy? Review of International Political Economy, Vol. 12, No. 1, pp. 1-25.

Hämmerli, B., and Renda, A. (2010). Protecting critical infrastructure in the EU. Brussels: Centre for European Policy Studies.

Harvey, D. (1985). The geopolitics of capitalism. In Gregory, D. and Urry, J. (eds), Social relations and spatial structures. Basingstoke: Macmillan, pp. $128-163$.

Harvey, D. (2010). The enigma of capital: And the crises of capitalism. New York: Oxford University Press.

Hass, E. B. (1958). The uniting of Europe: Political, social, and economical forces, 1950-1957. Notre Dame, IN: University of Notre Dame Press.

Heeg, S., and Ossenbrügge, J. (2002). State formation and territoriality in the European Union. Geopolitics, Vol. 7, No. 3, pp. 75-88.

Held, D., McGrew, A., Goldblatt, D., and Perraton, J. (2000). Global transformations: Politics, economics and culture. London: Palgrave Macmillan.

Hettne, B. (2005). Beyond the 'new' regionalism. New Political Economy, Vol. 10 , No. 4, pp. 543-571.

Hettne, B., and Söderbaum, F. (1998). The new regionalism approach. Politeia, Vol. 17, No. 3, pp. 6-21.

Hettne, B., and Söderbaum, F. (2000). Theorising the rise of regionness. New Political Economy, Vol. 5, No. 3, pp. 457-474.

Hickel, J., and Kallis, G. (2019). Is green growth possible? New Political Economy, Vol. 25, No. 4, pp. 1-18.

Högselius, P., Åberg, A., and Kaijser, A. (2013). Natural gas in cold war Europe: The making of a critical infrastructure. In Högselius, P., Hommels, A., Kaijser, A., and Van der Vleuten, E. (eds), The making of Europe's critical infrastruc- 
ture: Common connections and shared vulnerabilities. Basingstoke: Palgrave Macmillan, pp. 27-61.

Holsti, K. (1996). The state, war, and the state of war. Cambridge: Cambridge University Press.

Howe, C., Lockrem, J., Appel, H., Hackett, E., Boyer, D., Hall, R., ... and Ballestero, A. (2016). Paradoxical infrastructures: Ruins, retrofit, and risk. Science, Technology, and Human Values, Vol. 41, No. 3, pp. 547-565.

Hurrell, A. (1995). Explaining the resurgence of regionalism in world politics. Review of International Studies, Vol. 21, No. 4, pp. 331-358.

Jackson, R. H., and James, A. (1993). The character of independent statehood. In Jackson, R. H. and James, A. (eds), States in a changing world. Oxford: Clarendon, pp. 3-25.

Johnson, D., and Turner, C. (1997). Trans-European networks: The political economy of integrating Europe's infrastructure. Basingstoke: Macmillan.

Johnson, D., and Turner, C. (2007). Strategy and policy for trans-European networks. Basingstoke: Palgrave Macmillan.

Kandiyoti, R. (2012). Pipelines: flowing oil and crude politics. London: IB Tauris.

Katzenstein, P. J. (ed.) (1978). Between power and plenty: Foreign economic policies of advanced industrial states. Madison: University of Wisconsin Press.

Katzenstein, P. J. (2003). Small states and small states revisited. New Political Economy, Vol. 8, No. 1, pp. 9-30.

Keating, M. (2013). Rescaling the European state: The making of territory and the rise of the meso. Oxford: Oxford University Press.

Keohane, R. O. (2002). Power and governance in a partially globalized world. London: Routledge.

Keohane, R. O., and Nye, J. S. (1975). International interdependence and integration. In Greenstein, F. I. and Polsby, N. W. (eds), Handbook of political science (Vol. 8). Reading, MA: Addison-Wesley, pp. 363-414.

Kofman, D. (2007). The normative limits to the dispersal of territorial sovereignty. The Monist, Vol. 90, No. 1, pp. 65-85.

Krasner, S. D. (1978). Defending the national interest: Raw materials investments and US foreign policy. Princeton, NJ: Princeton University Press.

Kurian, N. (2004). Fungible borders and informal regionalism: Rethinking China's international relations. East Asia, Vol. 21, No. 1, pp. 7-17.

Larkin, B. (2013). The politics and poetics of infrastructure. Annual Review of Anthropology, Vol. 42, pp. 327-343.

Lemay-Hébert, N. (2009). Statebuilding without nation-building? Legitimacy, state failure and the limits of the institutionalist approach, Journal of Intervention and Statebuilding, Vol. 3, No. 1, pp. 21-45.

Mamadouh, V. (2001). The territoriality of European integration and the territorial features of the European Union: The first 50 years. Tijdschrift voor economische en sociale geografie, Vol. 92, No. 4, pp. 420-436.

Mann, M. (1984). The autonomous power of the state: Its origins, mechanisms and results. European Journal of Sociology, Vol. 25, No. 2, pp. 185-213.

Mann, M. (1997). Has globalization ended the rise and rise of the nation-state? Review of International Political Economy, Vol. 4, No. 3, pp. 472-496. 
Marvin, S., and Graham, S. (2001). Splintering Urbanism: Networked infrastructures, technological mobilities and the urban condition. London: Taylor \& Francis.

Martin, P., and Rogers, C. A. (1995). Industrial location and public infrastructure. Journal of International Economics, Vol. 39, No. 3-4, pp. 335-351.

Misa, T. J., and Schot, J. (2005). Introduction: Inventing Europe: Technology and the hidden integration of Europe. History and Technology, Vol. 21, No. 1, pp. 1-19.

Mitchell, T. (1991). The limits of the state: Beyond statist approaches and their critics. American Political Science Review, Vol. 85, No. 1, pp. 77-96.

Moravcsik, A. (1993). Preferences and power in the European Community: a liberal intergovernmentalist approach. JCMS: Journal of Common Market Studies, Vol. 31, No. 4, pp. 473-524.

Moisio, S. (2019). Re-thinking geoeconomics: Towards a political geography of economic geographies. Geography Compass, Vol. 13, No. 10, e12466.

Murphy, A. B. (2013). Trapped in the logic of the modern state system? European integration in the wake of the financial crisis. Geopolitics, Vol. 18, No. 3, pp. 705-723.

Newman, D., and Paasi, A. (1998). Fences and neighbours in the postmodern world: Boundary narratives in political geography. Progress in Human Geography, Vol. 22, No. 2, pp. 186-207.

Niskanen, W. A. (1991). The soft infrastructure of a market economy. Cato Journal, Vol. 11, No. 2, pp. 233-238.

Nordlinger, E. A., Lowi, T. J., and Fabbrini, S. (1988). The return to the state: Critiques. American Political Science Review, Vol. 82, No. 3, pp. 875-901.

O'Tuathail, G., Herod, A., and Roberts, S.M. (1998). Negotiating unruly problematics. In Herod, A., O'Tuathail, G., and Roberts, S. M. (eds), An unruly world? Globalization, governance and geography. London: Routledge, pp. 1-24.

Opitz, S., and Tellmann, U. (2015). Europe as infrastructure: Networking the operative community. South Atlantic Quarterly, Vol. 114, No. 1, pp. 171-190.

Pace, M. (2007). The construction of EU normative power. JCMS: Journal of Common Market Studies, Vol. 45, No. 5, pp. 1041-1064.

Painter, J. (2010). Rethinking territory. Antipode, Vol. 42, No. 5, pp. 1090-1118.

Painter, J., and Jeffrey, A. (2009). Political geography. London: Sage.

Palan, R., and Abbott, J. with Phil Deans (2001). State strategies in the global political economy. London: Pinter.

Payne, A., and Gamble A. (1996). Introduction: The political economy of regionalism and world order. In Gamble, A. and Payne, A. (eds), Regionalism and world order. Basingstoke; Macmillan, pp. 1-20.

Perkmann, M. (2007). Construction of new territorial scales: A framework and case study of the EUREGIO cross-border region. Regional Studies, Vol. 41, pp. 253-266.

Pullano, T. (2011). The evolving category of territory: From the modern state to the European Union. Warwick: University of Warwick, Centre for the Study of Globalisation and Regionalisation. 
Pursiainen, C. (2009). The challenges for European critical infrastructure protection. European Integration, Vol. 31, No. 6, pp. 721-39.

Rinaldi, S. M., Peerenboom, J. P., and Kelly, T. K. (2001). Identifying, understanding, and analysing critical infrastructure interdependencies. IEEE Control Systems, Vol. 21, No. 6, pp. 11-25.

Rosamond, B. (2000). Theories of European integration. Basingstoke: Palgrave Macmillan.

Sack, R. D. (1983). Human territoriality: A theory. Annals of the Association of American Geographers, Vol. 73, No. 1, pp. 55-74.

Sack, R. (1986). Human territoriality: Its theory and history. Cambridge: Cambridge University Press.

Sassen, S. (2013). When territory deborders territoriality. Territory, Politics, Governance, Vol. 1, No. 1, pp. 21-45.

Schimmelfennig, F. (2010). Integration theory. In Egan, M., Nugent, N., and Paterson, W. (eds), Research agendas in EU studies. Basingstoke: Palgrave Macmillan, pp. 37-59.

Schipper, F., and Schot, J. (2011). Infrastructural Europeanism, or the project of building Europe on infrastructures: An introduction. History and Technology, Vol. 27, No. 3, pp. 245-264.

Schipper, F., and Van der Vleuten, E. (2008). Trans-European network development and governance in historical perspective. Network Industries Quarterly, Vol. 10, No. 3, pp. 5-7.

Schmitter, P. (2007). Regional cooperation and region integration: Concepts, measurements and a bit of theory. Unpublished manuscript. European University Institute, Fiosele, Italy.

Scholte, J. A. (2005). Globalization: A critical introduction. Basingstoke: Macmillan.

Scott, J. W. (2009). Bordering and ordering the European neighbourhood: a critical perspective on EU territoriality and geopolitics. Trames, Vol. 13, No. 3, pp. 232-247.

Scott, J. W., and Van Houtum, H. (2009). Reflections on EU territoriality and the 'bordering' of Europe. Political Geography, Vol. 28, No. 5, pp. 271-273.

Skocpol, T. (1985). Strategies of analysis in current research. In Rueschemeyer, D., Evans, P. B., and Skocpol, T. (eds), Bringing the state back in. Cambridge: Cambridge University Press, pp. 3-43.

Skocpol, T., and Theda, S. (1979). States and social revolutions: A comparative analysis of France, Russia and China. Cambridge: Cambridge University Press.

Smith, P. H. (1992). Introduction: The politics of integration: Concepts and themes. In Smith, P. H. (ed.), The challenge of integration: Europe and the Americas. New Brunswick, NJ: Transaction, pp. 5-39.

Söderbaum, F. (2012). Formal and informal regionalism. In Shaw, T. M., Grant, J. A., and Cornelissen, S. (eds), The Ashgate research companion to regionalisms. Aldershot: Ashgate, pp. 51-67.

Sohn, C. (2014). Modelling cross-border integration: The role of borders as a resource. Geopolitics, Vol. 19, No. 3, pp. 587-608. 
Star, S. L. (1999). The ethnography of infrastructure. American Behavioral Scientist, Vol. 43, No. 3, pp. 377-391.

Star, S. L., and Ruhleder, K. (1996). Steps toward an ecology of infrastructure: Design and access for large information spaces. Information Systems Research, Vol. 7, No. 1, pp. 111-134.

Taylor, P. J. (1994). The state as container: Territoriality in the modern world-system. Progress in Human Geography, Vol. 18, No. 2, pp. 151-162.

Taylor, P. J. (1995). Beyond containers: Internationality, interstateness, interterritoriality. Progress in Human Geography, Vol. 19, No. 1, pp. 1-15.

Turner, C. (2018). Regional infrastructure systems: The political economy of regional infrastructure. Cheltenham, UK and Northampton, MA, USA: Edward Elgar Publishing.

Turner, C. (2020). The infrastructured state. Cheltenham, UK and Northampton, MA, USA: Edward Elgar Publishing.

Turner, C., and Johnson, D. (2017). Global infrastructure networks: The trans-national strategy and policy interface. Cheltenham, UK and Northampton, MA, USA: Edward Elgar Publishing.

Van der Vleuten, E. (2004). Infrastructures and societal change: A view from the large technical systems field. Technology Analysis and Strategic Management, Vol. 16, No. 3, pp. 395-414.

Van der Vleuten, E. and Kaijser, A. (2005). Networking Europe. History and Technology, Vol. 21, No. 1, pp. 21-48.

Van der Vleuten, E., and Kaijser, A. (eds) (2006). Networking Europe: Transnational infrastructures and the shaping of Europe, 1850-2000. Sagamore Beach, MA: Science History Publications.

Van der Vleuten, E., and Lagendijk, V. (2010). Interpreting transnational infrastructure vulnerability: European blackout and the historical dynamics of transnational electricity governance. Energy Policy, Vol. 38, No. 4, pp. 2053-2062.

Van der Vleuten, E., Högselius, P., Hommels, A., and Kaijser. A. (2013). Europe's critical infrastructures and its vulnerabilities: Promises, problems, paradoxes. In Högselius, P., Hommels, A., Kaijser, A., and Van der Vleuten, E. (eds), The making of Europe's critical infrastructure: Common connections and shared vulnerabilities. Basingstoke: Palgrave Macmillan, pp. 3-19.

Vaubel, R., and Willett, T. D. (eds) (1991). The political economy of international organizations: A public choice approach. Boulder, CO: Westview.

Vitale, A. (2011). The contemporary EU's notion of territoriality and external borders. European Spatial Research and Policy, Vol. 18, No. 2, pp. 17-27.

Vollaard, H. (2009). The logic of political territoriality. Geopolitics, Vol. 14, No. 4, pp. 687-706.

Wallace, W. (1999). The sharing of sovereignty: The European paradox. Political Studies, Vol. 47, No. 3, pp. 503-521.

Walters, W. (2004). The frontiers of the European Union: A geostrategic perspective. Geopolitics, Vol. 9, No. 3), pp. 674-698.

Weber, M. (1968). Economy and society. New York: Bedminster.

Weiss, L. (1998). The myth of the powerless state. Cambridge: Polity Press. 
Weiss, L. (2005). The state-augmenting effects of globalisation. New Political Economy, Vol. 10, No. 3, pp. 345-353.

Wissel, J. (2014). The structure of the 'EU'ropean ensemble of state apparatuses and its geopolitical ambitions. Geopolitics, Vol. 19, No. 3, pp. 490-513.

World Bank (2012). Inclusive green growth: The pathway to sustainable development. Washington, DC: World Bank. 